\title{
FARM AS A FORM OF SMALL AGRICULTURAL BUSINESS IN RUSSIA: ADVANTAGES AND DISADVANTAGES
}

\author{
Tatiana Evteeva \\ Slovak University of Agriculture in Nitra \\ Nitra, Slovak Republic \\ tanyaevt@mail.ru \\ Patrik Rovný \\ Slovak University of Agriculture in Nitra \\ Nitra, Slovak Republic \\ patrik.rovny@gmail.com

\section{Marek Petril'ák} \\ Slovak University of Agriculture in Nitra \\ Nitra, Slovak Republic \\ m.petrilak93@gmail.com
}

\begin{abstract}
Small business in the Russian Federation is actively developing not only in large cities, but also in small rural settlements. This is facilitated by the demand for agricultural products grown in ecologically clean territory. In addition, the Ministry of Agriculture of the Russian Federation is developing support programs for rural entrepreneurs, which allows you to start a business without high costs. This paper discusses farming in detail as the form of small agricultural business. The theoretical part involves an analysis of the essence of the concept of a farm, the legislative aspect, the process of opening and the difference from other forms of management. From a practical point of view, the place of farms in the Russian Federation was determined in the structure of agricultural production. The study was conducted by systemic and monographic methods. As a result, the advantages, disadvantages and prospects for the development of farming in Russia were identified.
\end{abstract}

KEYWORDS: agriculture, agricultural business, farms, production structure, Russia

JEL CLASSIFICATION: F15, L88, P25, Q02, Q13-

\author{
Received: November $27^{\text {th }}, 2019$ \\ 1st Revision: December $14^{\text {th }}, 2019$ \\ Accepted: December 18 $8^{\text {th }}, 2019$ \\ DOI: 10.2478/IJEK-2019-0010
}

Reference: Evteeva, T., Rovný, P. \& Petril'ak, M. (2019). Farm as a form of small agricultural business in russia: advantages and disadvantages. International Journal of Entrepreneurial Knowledge, 7(2), 53-62. doi:10.12345-0010

\section{INTRODUCTION}

In the modern agricultural sector of Russia, there are many forms of agricultural business, which are based on private ownership, participation in the market, meeting the needs of agricultural consumers, generating income and economic security. One of these forms of farming is farming. (O. Shumakova, 2014) The key problems in the development of farming in Russia remain the complexity of product sales, low profit, feed and fuel prices. For the normal functioning of such an economy, the level of economic efficiency is important, which is provided not only by the farm itself, but also by the level of state support and the influence of natural and climatic conditions (Shvindt E.I., 2014).

The study of peasant (farmer) farms was actively engaged by such scientists as Chayanov A.V., Chelintsev A.N., Shmelev G.I., Nikonov A.A., Kryuchkov V.T., Serova E.V., Sharafanova E .E. and 
many others, referring their activities to the types of economic activity of the population. This is evidenced by numerous publications related to this issue (Belova T., 2015).

Russian Agrarian Reform of the 1990s implied the creation of small family farms, which were to replace the already ineffective Soviet collective farms and state farms (Barsukova S., 2016).

According to the results of the 2006 agricultural census, 253.1 thousand farms control only $15.5 \%$ of all agricultural territories in Russia versus 59.2 thousand agricultural organizations $(21 \%$ of them are agricultural holdings), $66.2 \%$ of which are controlled all agricultural territories (Federal State Statistic Service, 2018).

10 years later, according to the final data of the 2016 All-Russian Agricultural Census, which were thoroughly analyzed in the 4th quarter of 2018, the number of farms over the past 10 years has decreased by $31 \%$ compared to the 2006 agricultural census. At the same time, the average land area of the farm over the past decade has more than doubled - by 57\% in 2016. The reason for this reduction is the consolidation of farms and the formation of agricultural holdings (Federal State Statistic Service, 2018, Ministry of Agriculture, 2019).

It is important to note that one of the most important areas for the development of the Russian agroindustrial complex in the context of the policy of import substitution is the increase in demand for high-quality domestic products. In this situation, a special function is performed by small agricultural enterprises, including farms, whose activity allows to intensify the entrepreneurial initiative of rural residents, create new jobs, and develop activities that farms are not always engaged in at present (Borisov D., 2010).

Despite a number of features, changes and factors of doing business over the past decades, farming still remains an attractive form of management. In this article we want to understand what farming represents as a business unit, and what are the arguments for and against farming in Russia.

\section{MATERIALS AND METHODS}

The works of domestic and foreign scientists, agricultural economists, researchers and agricultural consultants were studied for a deep and detailed investigation of the problem. For analysis, comparison and conclusions, we used a combination of statistical data both separately for farms and for agriculture as a whole in Russia, agricultural census data for several periods, federal laws on the regulation of small agricultural enterprises (Enina D., 2018).

The initial data were investigated by methods of systemic and monographic analysis.

From the point of view of a theoretical study, the data obtained were processed by abstracting, analyzing and synthesizing. Studying the problems of farms among other forms of small agricultural business is based on the method of deduction. Identification of advantages, disadvantages, or problems and positive trends by induction.

From the point of view of practical research, the results were analyzed by empirical methods: monitoring the process and the results of farm activities over a number of years, description - recording information on the functioning of farms for a certain period of time: using the results of an agricultural census for decades, the opinions of farmers, consultants and specialists in management issues, measurement - the number of farms operating in a particular field of agriculture in a certain IRS time, their productivity, the number of comparison - comparison of the base year previous to identify trends. (Derunova, E., 2012)

On the basis of the results obtained, clear conclusions were formulated on the problem under study.

\section{THEORETICAL BASIS}

Peasant farms in the Russian Federation engaged in the production of agricultural products are included in the second sphere of the agro-industrial complex (N. Kovolenko, 2017). 
The main activity of farms is traditionally the production of agricultural products, with the successful development of the farm, processing can be organized. But farms can engage in other activities that are not prohibited by law, including those not related to the production of agricultural products. Therefore, in farming, agricultural production can be successfully combined with other types of activities based on the use of local resources: serving tourists, raising wild animals and providing services to hunters, developing a variety of crafts, consumer services, etc. Due to the difficult situation in the economy at present most of the farms combine the production of agricultural products with the provision of construction, transportation services and the like (Kiselev S., 2010).

An enterprise is called a farm if at least $70 \%$ of the total profit is derived from agricultural products (Petrovchuk L. A, 2015).

According to the Federal Law of June 11, 2003 N 74-FL (as amended on June 23, 2014) "On Peasant (Farm) Farming" in the Russian Federation, a Peasant farm is an association of citizens related by kinship (spouses, their parents, children, brothers, sisters, grandchildren, as well as grandfathers and grandmothers of each spouse, but not more than three families, and (or) citizens who are not related to the head of the farm. The maximum number of such citizens may not exceed five people with joint ownership of property and jointly They are involved in production and other economic activities (production, processing, storage, transportation and sale of agricultural products) based on their personal participation (Federal Law of June 11, 2003 N 74-FL RF). An enterprise is created by a group of people or a single person (individual entrepreneur), without or with the formation of a legal entity (the formation of a legal entity is regulated by Article 86.1 of the 4th chapter of the Civil Code of Russia).

A farm as a legal entity is a voluntary association of citizens on the basis of membership for joint production or other economic activities in the field of agriculture, based on their personal participation and association of property contributions by members of the farm.

The main provisions on which farm activity in Russia is based on the Federal Law of 11.06.2003 N 74FL:

- The unification of citizens must occur strictly on the principles of voluntariness;

- The personal participation of each member of the economy in its activities is assumed;

- A citizen has the right to be a member of only one farm with the status of a legal entity;

- In the case of collection of debt from the farm, the sale of its property should be carried out at public auction.

- All members of the holding are responsible for each other - if one cannot fulfill his obligations, the others must do so (Federal Law of June 11, 2003 N 74-FL RF).

For the purpose of coordinating their business activities, representing and protecting common property interests, farms can create associations in the form of associations or unions of farms on territorial and sectoral grounds, and can also be founders, participants, members of commercial and non-profit organizations.

Thus, in Russia there are three types of farms: an individual entrepreneur, who is the head of the farm or acting alone, the farm as a contractual association and as the legal form of a legal entity (Petrovchuk L., 2015).

Not only the private interests of farm members are ensured in carrying out entrepreneurial activities within the framework of a farm. The revival of agriculture, the provision of agricultural products on the commodity market is able to solve problems of national importance, thereby ensuring the public interests of the state and society (Elkina O., 2010).

\section{PRACTICAL BASIS}

Farms were developed in the process of reforming the agriculture of the Russian Federation, (Kovolenko N, 2017). By the end of 2016, there were 174.8 thousand units of farms, they occupied 22.1 million hectares of sown area, which amounted to about $27.7 \%$ of sown area in farms of all categories in the country. In general, the share of farms and households accounted for $16.5 \%$ of the 
total agricultural land area - 57.6 million hectares. The average farm land is 226 hectares (All-Russian Agricultural Census 2016).

In recent years, the process of creating farms has slowed down somewhat and their agricultural activity has decreased. So, if in 1991 there were 49 thousand farms, in 1997 - 280.1 thousand, in 2005 - 257.4 thousand, in 2012 - 255.4 thousand, and in 2016 - 174.8 thousand (Census 2016, Federal State Statistic Service, 2018).

18541 units of farms and 853.9 thousand individual entrepreneurs were registered during 2018. Along with the creation of new farms, there is a process of their collapse. In 1993, 14 thousand households ceased to exist, in 1997 - 12.9 thousand, and in 2014 compared to 2012, the number decreased by 14.4 thousand households, in 201821 ceased operations. 7 thousand households (Federal tax service of Russia, 2018). In 2013, small businesses accounted for $52 \%$ of gross agricultural output, including potato $-86.9 \%$, vegetables $-82.9 \%$, milk $53.7 \%$ and meat $-33.1 \%$. In value terms, the volume of agricultural production from farms and personal subsidiary plots amounted to 1943.7 billion roubles (45.8 billion euros at the exchange rate of 2013). Gross harvests of grain and leguminous crops for the period 2005-2015 increased by 33.5\%, sunflower - by $35 \%$, vegetables - by $32 \%$, potatoes - by $10.5 \%$. Thus, the growth rate of production in the agricultural sector over the past 10 years is 2.3 times higher than in the industry. The second sector of the agro-industrial complex produces almost $45 \%$ of final products. It involves more than $65 \%$ of fixed assets and $56 \%$ of the number of employees (Kovolenko N., 2017).

Let's consider in more detail the structure of agricultural production in Russia by categories of organization.

\section{Table 1 The production structure of basic crop products by type of agricultural producers, $\%$}

\begin{tabular}{|c|c|c|c|c|c|c|c|c|c|c|c|c|}
\hline \multirow[t]{2}{*}{ Year } & \multicolumn{3}{|c|}{ Cereals and Legumes } & \multicolumn{3}{|c|}{ Sunflower } & \multicolumn{3}{|c|}{ Potatoes } & \multicolumn{3}{|c|}{ Vegetables } \\
\hline & 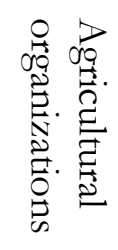 & \begin{tabular}{l} 
Tे \\
है \\
\multirow{5}{*}{}
\end{tabular} & $\begin{array}{l}7 \\
2 \\
5 \\
0 \\
0 \\
0 \\
0 \\
\frac{0}{2}\end{array}$ & 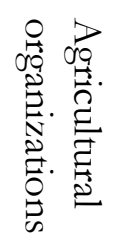 & 蛋 & $\begin{array}{l}T \\
0 \\
0 \\
0 \\
0 \\
0 \\
0 \\
\frac{0}{2}\end{array}$ & 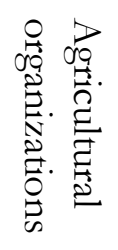 & 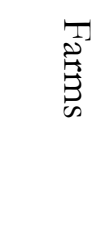 & \begin{tabular}{l}
$T$ \\
$\frac{T}{0}$ \\
\multirow{1}{0}{} \\
0 \\
0 \\
0 \\
$\frac{0}{2}$
\end{tabular} & 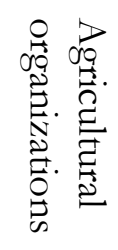 & $\begin{array}{l}\text { Tे } \\
\stackrel{2}{5} \\
\stackrel{5}{5}\end{array}$ & $\begin{array}{l}\text { I } \\
0 \\
0 \\
0 \\
0 \\
0 \\
0 \\
0 \\
0\end{array}$ \\
\hline 1990 & 99.7 & 0.0 & 0.3 & 98.6 & 0.0 & 1.4 & 33.9 & 0.0 & 66.1 & 69.9 & 0.0 & 30.1 \\
\hline 1995 & 94.4 & 4.7 & 0.9 & 86.3 & 12.3 & 1.4 & 9.2 & 0.9 & 89.9 & 25.3 & 1.3 & 73.4 \\
\hline 2000 & 90.8 & 8.4 & 0.8 & 84.3 & 14.5 & 1.2 & 7.5 & 1.3 & 91.2 & 22.9 & 2.4 & 74.7 \\
\hline 2005 & 80.6 & 18.3 & 1.1 & 72.1 & 27.4 & 0.5 & 8.4 & 2.8 & 88.8 & 18.7 & 6.9 & 74.4 \\
\hline 2010 & 77.1 & 21.9 & 1.0 & 73.0 & 26.4 & 0.6 & 10.5 & 5.5 & 84.0 & 17.1 & 11.4 & 71.5 \\
\hline 2015 & 72.7 & 26.3 & 1.0 & 70.3 & 29.3 & 0.4 & 13.8 & 8.6 & 77.6 & 17.9 & 15.1 & 67.0 \\
\hline 2016 & 71.1 & 28.0 & 0.9 & 67.2 & 32.4 & 0.4 & 13.5 & 8.5 & 78.0 & 18.7 & 14.6 & 66.7 \\
\hline
\end{tabular}

(Source: Federal State Statistic Service, 2018)

Table 1 shows the data on crop production by farm categories from the beginning of the agrarian reform in 1990 to the results of the 2016 agricultural census. As far as large agricultural organizations are concerned, there is a tendency to decrease production for all types of crop production during the study period, this is due to outdated agricultural machinery, high fuel prices, a drop in labour productivity, as fewer and fewer people work in agriculture, importing products into the non-seasonal period still remains at a significant level, the measures of state support provided for by the Agricultural Development Program 2013-2020 are starting to apply wider just in the last 3 years. Farms and individual entrepreneurs are increasing production from year to year. The state is actively developing supporting programs for small agricultural business, such as a grant to support young farmers, family livestock farms, a grant for initiatives and the like. In households, the growth of potato and vegetable 
production was especially marked in comparison with 1990 and 1995, but further to the base year there was a decrease in the productivity of potatoes and vegetables, which is associated with a change in the way of life in rural areas.

\section{Figure 1 Share in the production of cereals and leguminous plants, $\%$}

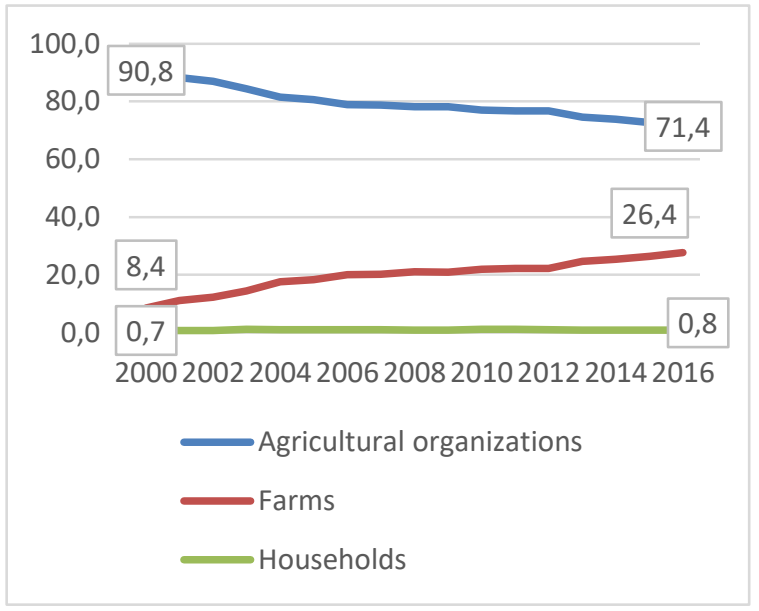

(Source: Federal State Statistic Service, 2018)

\section{Figure 2 Share in the production of sunflowers, $\%$}

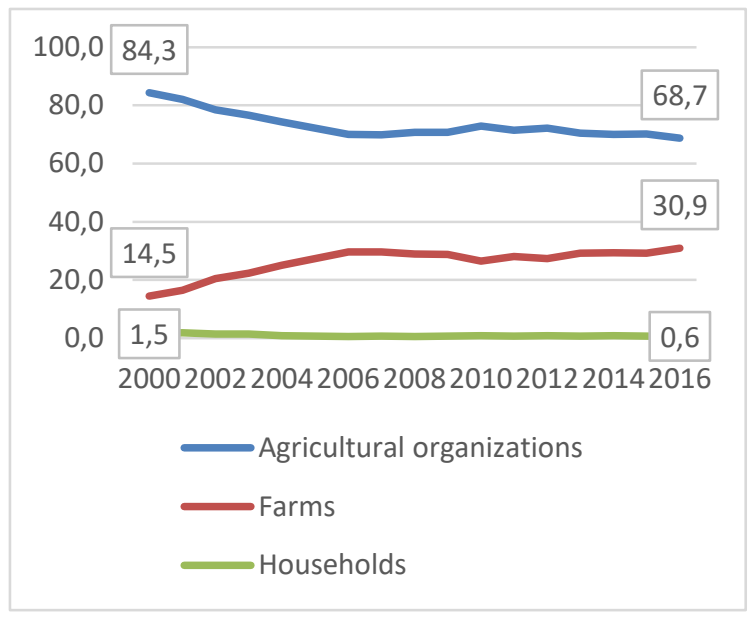

(Source: Federal State Statistic Service, 2018)

Figures 1 and 2 show the dynamics of the share of cereals, legumes and sunflower production. The main producers of cereals and legumes in Russia are agricultural organizations, followed by farms, and over 16 years the dynamics of production increased by $18 \%$. The main producer of sunflower is also agricultural organizations, the second place is taken by farms, in which production also increased by $16.4 \%$ over the study period. In the national economies of grain, legumes and sunflower, no more than $1.5 \%$ is produced for the study period.

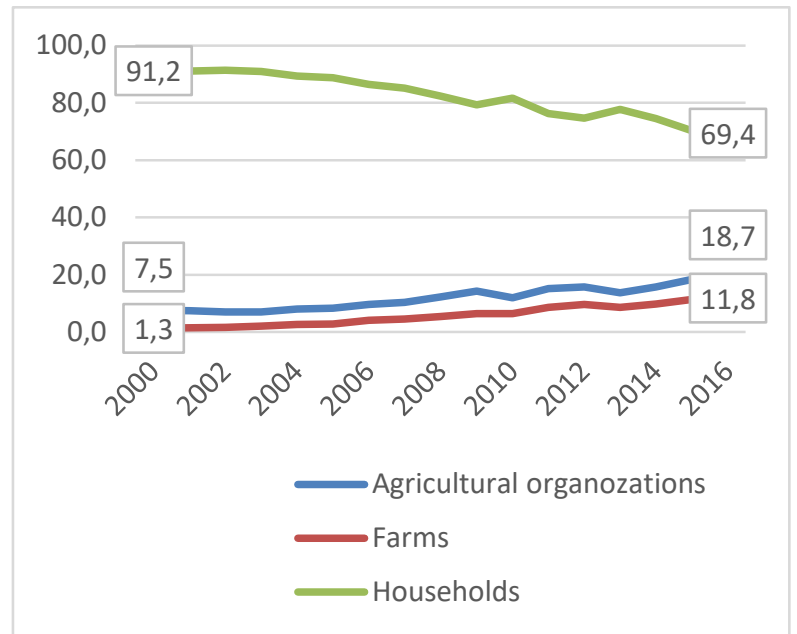

Figure 3 Share in the production of potato, $\%$

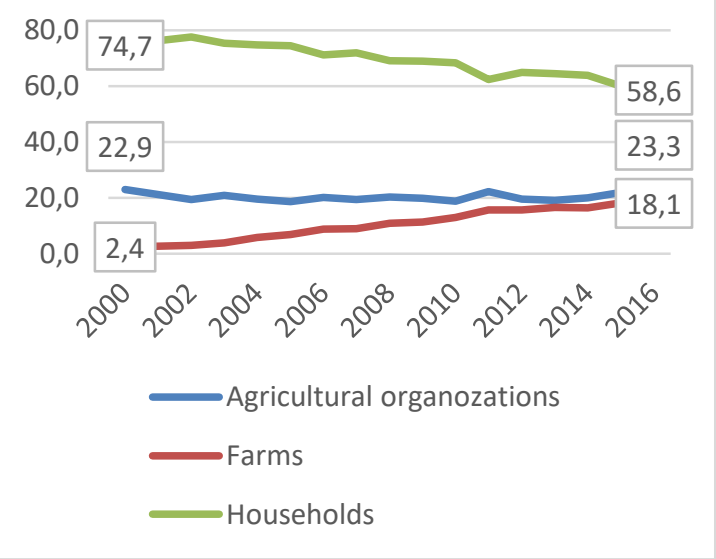

Figure 4 Share in the production of vegetables, $\%$

(Source: Federal State Statistic Service, 2018)

(Source: Federal State Statistic Service, 2018)

Figures 3 and 4 show the dynamics of the share of production of potatoes and vegetables. The main producers of potatoes are households, but during the study period, production from year to year is reduced and decreased by $21.8 \%$. Agricultural organizations are in the second place, where the growth 
is $11.2 \%$ for the study period, farms are in third place, where the growth of potato production is $10.5 \%$. The main producer of vegetables is also the national economy, over the study period, the share of vegetable production decreased by $16.1 \%$. Agricultural organizations with a production share of up to $23 \%$ are in the second place in terms of productivity. Farms are in last place, the productivity of vegetables on farms is growing from year to year, there is an increase of $15.7 \%$ for the study period.

Next, we consider the structure of livestock production by categories of producers.

\section{Table 2 The production structure of basic livestock products by type of agricultural producers, $\%$}

\begin{tabular}{|c|c|c|c|c|c|}
\hline & 1990 & 2000 & 2006 & 2010 & 2016 \\
\hline \multicolumn{6}{|l|}{ Cattle } \\
\hline $\begin{array}{l}\text { Agricultural } \\
\text { organization }\end{array}$ & 86,8 & 43 & 32,7 & 31,9 & 32,6 \\
\hline Farms & 0,01 & 1,79 & 4,7 & 7,9 & 8,4 \\
\hline Households & 13,2 & 55,2 & 62,6 & 60,2 & 58,9 \\
\hline \multicolumn{6}{|l|}{$\begin{array}{l}\text { Milk } \\
\text { production }\end{array}$} \\
\hline $\begin{array}{l}\text { Agricultural } \\
\text { organization }\end{array}$ & 76,2 & 47,3 & 44,9 & 47,8 & 49 \\
\hline Farms & 0 & 1,76 & 4,7 & 6,6 & 7,0 \\
\hline Households & 23,8 & 50,9 & 50,4 & 45,6 & 44 \\
\hline \multicolumn{6}{|l|}{$\begin{array}{l}\text { Pork } \\
\text { production }\end{array}$} \\
\hline $\begin{array}{l}\text { Agricultural } \\
\text { organization }\end{array}$ & 65,8 & 27,6 & 52,7 & 78,2 & 80,5 \\
\hline Farms & 0,01 & 2,23 & 3 & 1,4 & 1,3 \\
\hline Households & 34,2 & 70,2 & 44,3 & 20,4 & 18,2 \\
\hline \multicolumn{6}{|l|}{ Poultry } \\
\hline $\begin{array}{l}\text { Agricultural } \\
\text { organization }\end{array}$ & 69,9 & 65,4 & 88,4 & 91,5 & 91,9 \\
\hline Farms & - & 0,39 & 0,6 & 1,1 & 1,0 \\
\hline Households & 30,1 & 34,2 & 11 & 7,4 & 7,1 \\
\hline \multicolumn{6}{|l|}{$\begin{array}{l}\text { Sheep and } \\
\text { goat }\end{array}$} \\
\hline $\begin{array}{l}\text { Agricultural } \\
\text { organization }\end{array}$ & 57,9 & 10,8 & 8,9 & 7,9 & 7,8 \\
\hline Farms & & 4,08 & 18,6 & 21,2 & 21,7 \\
\hline Households & 42,1 & 85,1 & 72,5 & 70,9 & 70,6 \\
\hline
\end{tabular}

(Source: Federal State Statistic Service, 2018)

Table 2 shows data on types of livestock products by category of producers in the study period from the beginning of the agrarian reform to the last agricultural census. There is a decreasing cattle production by agricultural organizations, there is a slight growth trend of $8.3 \%$ on farms, in contrast to households, where the growth at the end of the study period is $20.2 \%$. Milk production in agricultural organizations also decreased, on the farms there was a slight increase, and in households the increase was almost 2 times. There was an increase for the study period in agricultural organizations involved in pork production, the average share of production does not exceed 1.6\% on farms, there is a decrease in the share of production by $16 \%$ in households. Agricultural organizations are successful in poultry production, the growth was $22 \%$ in the households, the share of production does not exceed $1 \%$ on farms, the share of production decreased by $23 \%$ over the study period. The production of sheep and 
goats among agricultural organizations decreased by 50\% for the study period, farms produce an average of no more than $20 \%$ of sheep and goat's production, and in households there is an increase in production by $28.5 \%$.

Figure 5 Share in the milk production, $\%$

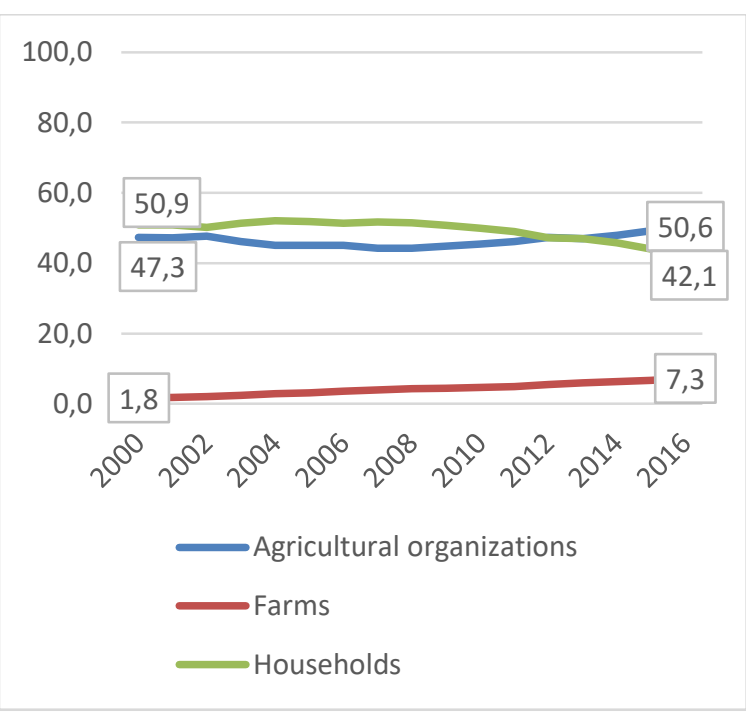

(Source: Federal State Statistic Service, 2018)
Figure 6 Share in the cattle production, \%

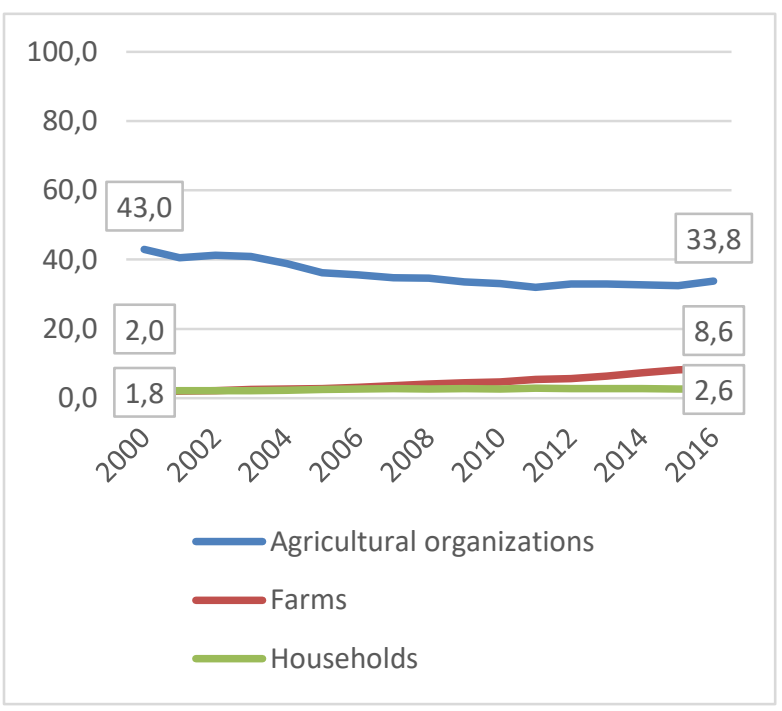

(Source: Federal State Statistic Service, 2018)

Figures 5 and 6 show the dynamics of milk and cattle production. Agricultural organizations are the first in milk production, although at the beginning of the study period the leaders were households. Farms occupy $7.3 \%$ of production at the end of the period. Agricultural organizations are the leaders in cattle production, but their productivity decreased by $9.2 \%$ over the study period. Farms ranked second in milk production, with growth of $6.6 \%$. The increase was less than $1 \%$ in households.

Figure 6 Share in the poultry production, $\%$

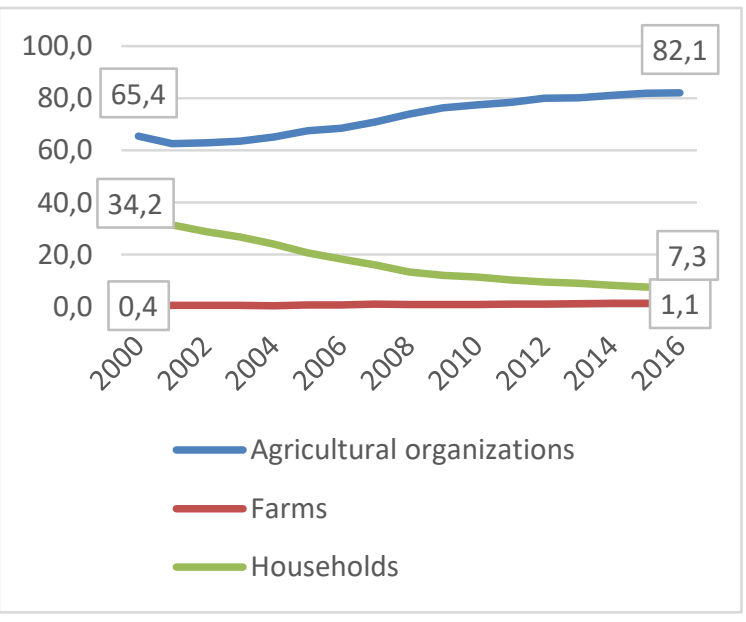

(Source: Federal State Statistic Service, 2018)
Figure 7 Share in the pork production, $\%$

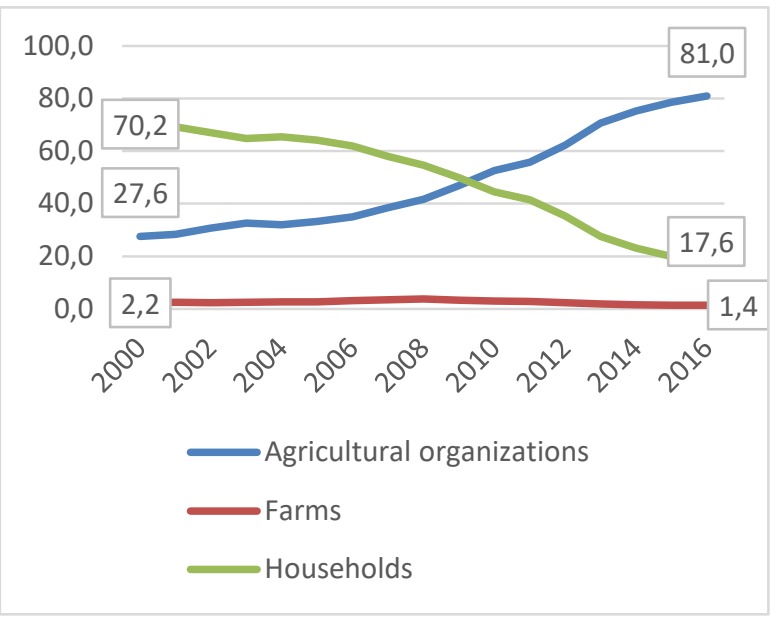

(Source: Federal State Statistic Service, 2018)

Figures 7 and 8 show the dynamics of poultry and pork production. The leader in poultry production is agricultural organizations with an increase of $16.7 \%$. Poultry production decreased by $26.9 \%$ in households. Farms produce no more than $1.1 \%$ of poultry products. The main producers in pork production are agricultural organizations, during the study period, productivity increased by $53.4 \%$, 
households fell to second place, but the share of production fell by $52.6 \%$, and farms produce no more than $2.2 \%$ of production.

\section{Figure 7 Share in the production of sheep and coat, $\%$}

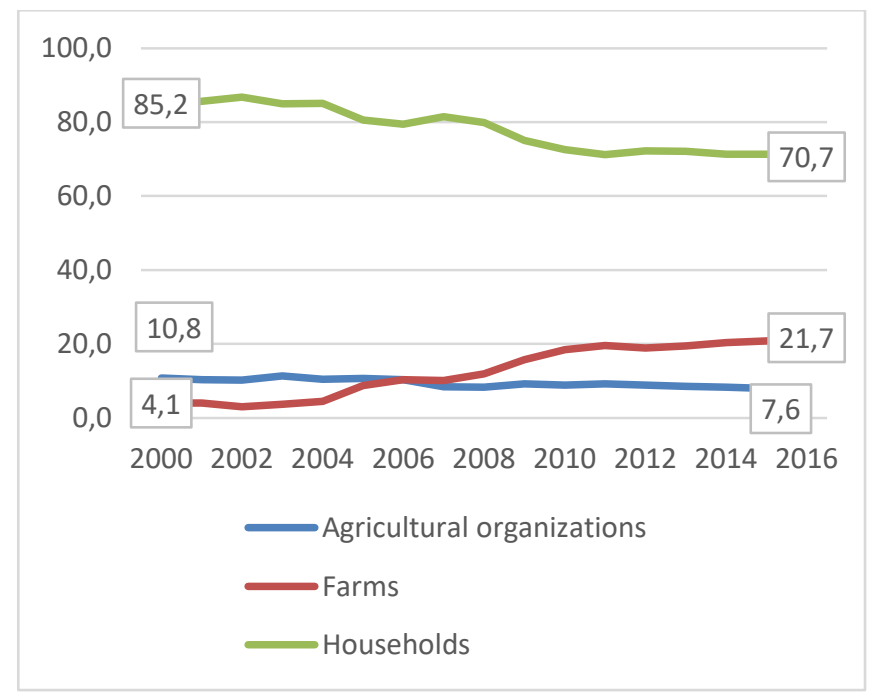

(Source: Federal State Statistic Service, 2018)

Figure 9 shows the dynamics of sheep and goat production. The leading producers are households, but in the study period, the share of production decreased by $14.5 \%$, farms have been the second largest producer of sheep and goats in recent years, their share has grown by $17.6 \%$, while the share of production in agricultural organizations has decreased by $3.2 \%$.

Based on the analysis of the agricultural production structure, the predominant form of agricultural business is agricultural organizations, farms are on the second place, the most productive areas in agriculture are the production of cereals, legumes and sunflowers, as well as the production of sheep and goats.

Thus, the structure of agricultural production in Russia was completely analysed for all categories of agricultural producers.

\section{CONCLUSION}

After a detailed analysis, the following advantages and disadvantages of farming as a form of small agricultural business can be distinguished.

Advantages:

- Personal choice of how to arrange an economy: individual entrepreneur or legal entity

- All members of the farm are equal owners of property

- To create such a form of management there are no requirements for the minimum authorized capital (for ordinary legal entities - from 140 euros).

- Registered farmers are more likely to receive state or municipal subsidies.

- Farms can receive land for activities on preferential treatments.

- Significantly less accountability volume compared to other forms of agricultural business. Disadvantages:

- The ability to attract only 5 people to the association who are not relatives. - For all members of the economy, personal participation in agricultural work is mandatory, which makes it difficult to attract new members and even more investors. 
- In case of financial problems at the farm, its members will have to bear personal responsibility, including at the expense of private property, because the legislation on farms has not been worked out enough, many areas are not regulated.

\section{Prospects:}

As the analysis of the structure of production has shown, at the moment there are few promising areas of crop production and animal husbandry for opening a farm. Farms occupy leading positions in none of the elements of the production structure unlike agricultural organizations and households. Moreover, at present, it is rather difficult to call Russian agriculture modern and prosperous. Despite the constant high demand for food products among the country population, the organization of production and access to the market require significant costs. This form of small agricultural business is suitable for large families living in rural areas. It makes it possible to rely on state aid, including the allocation of land and at the same time does not burden the owners with paper bureaucracy.

\section{REFERENCES}

Barsukova, S. Y. (2016) The farmers and agricultural holdings: dilemma in the context of import substitution. Journal: Social sciences and modernity, 5 (37), 23-28, ISSN: 0869-0499

Belova, T. M. (2015) Peasant farms and population facilities as a material base of development of agricultural activities of subsidiary regions. Journal: service in Russia and abroad, 4(60), 3-15. https://doi.org/10.12737/16080

Borisov, D.V., (2010) Peasant farms of the Altai region: problems and ways of development. Journal: Bulletin of Altai State Agrarian University, 4(66), 118-122, ISSN: 1996-4277

Bradley, M. E. (1973). Incentives and Labour Supply on Soviet Collective Farms: Reply, 6(3), 438-442, https://doi.org 10.2307/133973

Cameron, N. (1973) Incentives and Labour Supply on Soviet Collective Farms: Rejoinder. The Canadian Journal of Economics / Revue canadienne d'Economique, 6(3), 442-444, https://doi.org10.2307/133974

Chaplina, H., Davidova S., Gortonb, M. (2004) Agricultural adjustment and the diversification of farm households and corporate farms in Central Europe. Journal of Rural Studies, 20(1), 61-77, https://doi.org/10.1016/S0743-0167(03)00043-3

Derunova, E.A. (2012) Methodical approaches to evaluating the efficiency of scientific and technical projects in the system of promoting scientific achievements in agriculture. Journal: Bulletin of Orlov state agricultural university, 2(35), 123-126, ISSN: 1990-3618

Elkina, O. S. (2010) Peasant farm as a form of family business organization. Journal: Bulletin of the Moscow University of the Ministry of Internal Affairs in Russia, 6 (24), 104-107, ISSN 2073-0454

Enina, D.V., Alekseenko, T. C. (2018) To the question of formation and development of peasant farms in Russia and the world. Journal: A-economics: economics and analytics, 1, 6-10, ISSN: 2500-0861

Haileslassiea, A., Craufurdb, P., Thiagarajahc, R., Kumarc, S., Whitbread, A. (2015). Empirical evaluation of sustainability of divergent farms in the dryland farming systems of India. Journal Ecological indicators, 60, 710-723, https://doi.org/10.1016/j.ecolind.2015.08.014

Hazell, P., Poulton, C., Wiggins, S., Dorward, A. (2010) The Future of Small Farms: Trajectories and Policy Priorities. Jurnal: World Development, 38(10), 1349-1361, https://doi.org/10.1016/j.worlddev.2009.06.012

Kiselev S.V., Belova E.V., Emelyanov A.M., Belugina T.A., Kharitonov N.S., Khozhainov N.T., Yastrebova O.K. (2010). Book: Agrarian economy, 572 p., ISBN: 978-5-16-002038-9

Kizos, T., Marin-Guirao, J., Georgiadi, M. Dimoula, S, EVAGGELOS Karatsolis, E., Mpartzas, A, Mpelali, A., Papaioannou., S (2011). Survival strategies of farm households and multifunctional farms in Greece. The geographical journal, 4 (177), 335-336, https://doi: 10.1111/j.1475-4959.2011. 00403.x 
Kibrom, T., Sibhatu, Vijesh, V. Krishna, Matin, Q. (2015). Production diversity and dietary diversity in smallholder farm households. Proceedings of the National Academy of Sciences of the United States of America, 112 (34), 10657-10662, https://doi.org/10.1073/pnas.1510982112

Kovolenko, N. Ya., Agirbov, Yu. Yu., Akhmetov, R. G., Sorokin, V.S., Chutcheva, Yu., V., (2017) Book: Economy of Agriculture, 407 p. ISBN: 9785534069204

Leslie, B. (2008). On Family Farms and Commodity Groups: Rural Livelihoods, Households and Development Policy in the Eastern Cape. Journal of African studies, 31(1), 157-181, https://doi.org/10.1080/02533950508628700

Lowder, S. K., Skoet, J., Raney, T. (2015). The Number, Size, and Distribution of Farms, Smallholder Farms, and Family Farms Worldwide. Journal World Development, 87, 16-29, https://doi.org/10.1016/j.worlddev.2015.10.041

Meert, H., Van Huylenbroeck, G., Vernimmen, T., Bourgeois, M., Hecke, E. (2005) Farm household survival strategies and diversification on marginal farms. Journal of Rural Studies, 1(21), 81-97 https://doi.org/10.1016/j.jrurstud.2004.08.007

Mendola, M. (2005). Farm Households Production Theories: A Review of Institutional and Behavioural Responses. SSRN Electronic Journal, 01, http://dx.doi.org/10.2139/ssrn.661021

Petrovchuk, L.A. (2015) Peasant farm: essence, legal status and role in the development of agriculture of the country. Article in the VI All-Russian scientific-practical conference proceeding book "Conceptual bases of strategic management of regional development in the conditions of global challenges", February, 5, 2015, 240245 Retrieved from https://elibrary.ru/download/elibrary_25551955_52931497.pdf

Shumakova, O. V., Shvindt E. I. (2014). Place of farms in the development of agriculture in the region. Article in the conference proceeding book "Institutional development: economy, management, social sphere, education", Omsk, Russia, April 29-30, 2014, 115-119. Retrieved from https://elibrary.ru/download/elibrary_22557593_81186959.htm

Tittonell, P. Muriuki A., Shepherd, Mugendi, D., Kaizzi, K., Okeyo J., Verchot, L., Coe R., Vanlauw, B. (2010). The diversity of rural livelihoods and their influence on soil fertility in agricultural systems of East Africa - A typology of smallholder farms. Journal Agricultural Systems, 103(2), 83-97, https://doi.org/10.1016/j.agsy.2009.10.001

Wiggins, S., Kirsten, J., Llambí L. (2009). The Future of Small Farms. Journal World Development, 38(10), 1341-1348, https://doi.org/10.1016/j.worlddev.2009.06.013

Association of Russian Farms and Agricultural Cooperatives, farmers support programs in Russia. Retrieved from https://www.akkor.ru/statya/6216-programmy-podderzhki-fermerov-vrossii.html

Civil Code of the Russian Federation (Part One) of November 30, 1994 N 51-FL, Article 86.1. Peasant farm.

Federal Law of the Russian Federation dated June 11, 2003 No. 74-FL "On Peasant Farms" Retrieved from: http://www.consultant.ru/document/cons_doc_LAW_42662/

Federal State Statistic Service (2018) Results of the All-Russian agricultural census 2016 year 7(8) 347 p. ISBN 978-5-4269-0066-0. Retrieved from https://gks.ru/storage/mediabank/VSXP_2016_T_7_web.pdf

Ministry of Agriculture, State program for the development of agriculture for 2013 - 2020. Retrieved from: http://mcx.ru/activity/state-support/programs/program-2013-2020/

Official statistics database of Russian Federation Federal State Statistic Service, 2018 Retrieved from https://www.gks.ru/enterprise_economy 